UDC 325.2.000.1

Submitted: 27.11.2018

LBC 66.3(2Poc),5

Accepted: 22.03.2019

\title{
RUSSIAN-SPEAKING GROUPS IN GERMANY: MOTIVATION FOR MIGRATION ${ }^{1}$
}

\author{
Viacheslav D. Popkov \\ Institute of Social Researches and Analytics, Kaluga, Russian Federation \\ Ekaterina A. Popkova \\ Bauman Moscow State Technical University Kaluga Branch (National Research University), \\ Kaluga, Russian Federation
}

\begin{abstract}
Introduction. The article considers motivation for migration of Russian-speaking groups who came to Germany from the territory of the former USSR countries. The article focuses on the analysis of ethnically privileged migrant groups - late migrants (Russian Germans) and quota refugees (Russian Jews) who came to Germany in the period of the late 1980s to mid-2000s. The aim of the research is to reveal the main reasons for and motives of the Russian-speaking group migration from the post-Soviet republics. The authors focus on the migration motives which have not been fully described, shown or analyzed in foreign research works, thus, enabling the readers to broaden their view on the migration of Russian-speaking groups to Germany. Methods. The research is based on qualitative methodology using the method of thematically-centered interview. The selection was done by the "snowball" method. Analysis. The authors carried out a comparative analysis of several research works with the results of the project conducted with Russian-speaking groups in Munich in 2005-2006 and 2011. The analyzed basis makes 43 interviews. The paper discusses the most questionable aspects regarding the ascertainment of the motivations of Russian Germans and Russian Jews for moving to Germany; it also compares the groups and reveals common features of migratory background characteristics to both of them. The paper gives special attention to ethnic motivations of migration which turn to be both pushing and pulling factors for both Russian-speaking groups. It also compares interpretations of significance of ethnicity and ethnic discrimination being the reasons for migration of Russian Germans and Russian Jews in the research works analyzed here. Results. The hypothesis is that after the USSR split ethnic discrimination of both groups may be considered on the basis of "wrong" ethnicity in the countries of exodus. The conclusion is drawn that discrimination on ethnic basis cannot be the main reason for migration of Russian Germans and Russian Jews to Germany. It is more probable that in the case of Russian-speaking groups we deal with "drifting" ethnicity which may be suggested to or imposed on individuals. The data presented in the article may be of great interest for improving the state policy of this country towards compatriots from abroad and working out migratory regulations.
\end{abstract}

Key words: migration reasons, "drifting” ethnicity, Russian-speaking groups, Germany, Russia, Russian Germans, Russian Jews, comparative analysis.

Citation. Popkov V.D., Popkova E.A. Russian-Speaking Groups in Germany: Motivation for Migration. Vestnik Volgogradskogo gosudarstvennogo universiteta. Seriya 4. Istoriya. Regionovedenie. Mezhdunarodnye otnosheniya [Science Journal of Volgograd State University. History. Area Studies. International Relations], 2020, vol. 25, no. 1, pp. 229-240. (in Russian). DOI: https://doi.org/10.15688/jvolsu4.2020.1.19

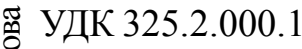

ББК $66.3(2 \mathrm{Poc}), 5$

Дата поступления статьи: 27.11.2018 Дата принятия статьи: 22.03.2019

\section{РУССКОЯЗЫЧНЫЕ ГРУППЫ В ГЕРМАНИИ: МИГРАЦИОННАЯ МОТИВАЦИЯ ${ }^{1}$}

\author{
Вячеслав Дмитриевич Попков
}

Институт социальных исследований и аналитики, г. Калуга, Российская Федерация 


\section{Екатерина Анатольевна Попкова}

Калужский филиал Московского государственного технического университета им. Н.Э. Баумана, г. Калуга, Российская Федерация

Аннотация. Введение. В статье рассмотрены миграционные мотивы русскоязычных групп, прибывших в Германию с территории бывшего Советского Союза и стран-наследниц СССР. Основной фокус анализа направлен на группы этнически привилегированных мигрантов - поздних переселенцев (русские немцы) и контингентных беженцев (русские евреи), прибывших в ФРГ в период с конца 1980-х до середины 2000-х годов. Ставится цель показать основные причины миграции русскоязычных групп из постсоветских стран и раскрыть их внутреннюю подоплеку. Meтоды. Исследование проводилось с опорой на качественную методологию с применением метода тематически-центрированного интервью. Выборка формировалась методом «снежного кома». Анализ. Авторами проведен сравнительный анализ некоторых исследований с результатами авторского проекта, проведенного среди русскоязычных групп в Мюнхене в 2005-2006 и 2011 годах. Всего было проведено 43 интервью. Дискутируются наиболее спорные аспекты, касающиеся выяснения миграционных мотивов русских немцев и русских евреев при переезде в Германию; также проводится межгрупповое сравнение и выявляются общие составляющие миграционной подоплеки, характерные для обеих русскоязычных групп. Значительное внимание уделяется этническим мотивам миграции, которые являются и выталкивающими, и одновременно притягивающими для обеих русскоязычных групп. Проводится сравнение интерпретаций значимости этничности и этнической дискриминации как причин миграции русских немцев и русских евреев. Результаты. Выдвигается гипотеза о том, что после распада СССР в новых странах исхода этническая дискриминация обеих групп может происходить по основанию «ложной» этничности. Предполагается, что в случае русскоязычных групп дело приходится иметь с изменяющейся этничностью, которая может быть предложена или навязана индивидам. Авторы статьи акцентируют внимание на миграционных мотивах русскоязычных групп, не получивших широкого освещения в зарубежных исследованиях, что позволяет читателям расширить представления о механизме миграции русскоязычных в Германию. Изложенные в статье результаты исследования могут быть востребованы для совершенствования государственной политики России в отношении соотечественников за рубежом и разработки регулирующих миграционных мероприятий. В.Д. Попков разработал дизайн проекта и осуществил общую научную редакцию статьи. Е.А. Попкова проанализировала работы зарубежных авторов и предложила схему исследовательского анализа.

Ключевые слова: причины миграции, «плавающая» этничность, русскоязычные группы, Германия, Россия, русские немцы, русские евреи, сравнительный анализ.

Цитирование. Попков В. Д., Попкова Е. А. Русскоязычные группы в Германии: миграционная мотивация // Вестник Волгоградского государственного университета. Серия 4, История. Регионоведение. Международные отношения. - 2020. - Т. 25, № 1. - C. 229-240. - DOI: https://doi.org/10.15688/jvolsu4.2020.1.19

Введение. Присутствие значительного количества мигрантов из бывшего Советского Союза и стран-наследниц СССР в Германии, прибывших в страну в конце XX в., пробудило пристальное внимание исследователей к проблеме их взаимодействия с принимающим обществом. Наряду с вопросами интеграции мигрантов, считающимися ключевыми в исследовательской среде, самое пристальное внимание уделяется миграционной составляющей проблемы, поскольку контекст миграции относится к одному из важных маркеров группы, с помощью которого объясняются обстоятельства ее выезда и приема. Главными являются два направления исследований, подразумевающие ответы на следующие ключевые вопросы: во-первых, почему мигранты хотели (или были вынуждены) покинуть пределы бывшего СССР; и, во-вторых, почему они выбрали Германию, как конечную цель миграции. Таким образом, в большинстве проведенных исследований речь идет не только об изучении добровольности или вынужденности миграции, что подразумевает выяснение значимости и интенсивности «выталкивающих факторов», но и о мотивах выбора страны нового поселения, которые характеризуются «притягивающими факторами». При этом особое значение придается оценке и сравнению мигрантами указанных аспектов, когда они еще находятся в стране исхода (до переезда) и когда они уже находятся в стране поселения (после переезда). Основное внимание исследователи уделяют этнически привилегированным мигрантам, под которыми понимаются немецкие переселенцы (русские немцы) 
и контингентные беженцы (русские евреи). Группа русских немщев юридически содержит в себе две категории: «переселенцев» (Aussiedler), прибывших до конца 1992 г., и «поздних переселенцев» (Spätaussiedler), прибывающих с 1993 года. Основной законодательной базой для иммиграции русских немцев является «Закон по делам изгнанных и беженцев» (Bundesvertriebenengesetz), вступивший в силу 19 мая 1953 г., и «Закон для урегулирования законов, вызванных последствиями войны» (Gesetz zur Bereinigung von Kriegsfolgengesetzen), вступивший в силу с начала 1993 года. В соответствии с последним документом был введен единый термин «поздних переселенцев», который получили и русские немцы. В группу русских евреев входят еврейские контингентные беженцы, мигрировавшие в Германию на основании закона «О мероприятиях в отношении беженцев, принятых в рамках акций гуманитарной помощи». Данный документ более известен в качестве «Закона о контингентных беженцах» (Kontingentflüchtlingsgesetz). Все участники данной группы, прибывшие в Германию до 1 января 2005 г., получали этот статус.

\section{Дискуссии.}

Случай русских немиев.

При определении основных мотивов выезда русских немцев многие исследователи подходят к проблеме с позиции репатриации, то есть возвращения группы на «историческую родину». Например, П. Кёддерицш в своем исследовании задает респондентам вопрос «почему Вы возвратились в Германию?», подчеркивая, что русские немцы - это не простые мигранты, а группа, которая возвращается домой, в свою страну. По его данным, $47 \%$ опрошенных указывают как причину «возвращения» желание «жить на родине предков». Это вторая по значимости причина переезда после «обеспечения надежного будущего для детей», на которую указали 68 \% респондентов [10, S. 38]. Характерно, что многие исследователи причину «жить на родине предков», чаще сформулированную в виде известного клише «жить как немцы среди немцев», отмечают в качестве одного из самых заметных мотивов переезда, который доминировал в течение длительного периода миграции.
Ряд исследователей отмечают смену приоритетов миграции русских немцев, которая пришлась на середину 90-х годов. Как считается, до этого периода в миграции русских немцев присутствовала этническая мотивация, а экономические причины не играли существенной роли. Как заметный стимул к переезду, они начинают упоминаться в исследованиях лишь с середины 90-х годов. В частности, И. Трёстер полагает, что до начала 90-х гг. основным мотивом переселенцев было желание жить «как немцы среди немцев», воссоединение семьи и забота о будущем детей. Однако русские немцы, приехавшие после 1993 г., «решались на переезд в первую очередь из-за напряженной экономической и политической ситуации в стране выезда» $[17, \mathrm{~S} .111-112]$. К. Фогель также подчеркивает, что с середины 90-х гг. начали превалировать экономические причины, связанные с «плачевным экономическим положением в РФ после распада СССР» [18, S. 25].

В то же время отмечается, что большинству переселенцев было известно, что ни советское правительство, ни немецкая сторона не признавали экономические причины в качестве приемлемых оснований для выезда. Поэтому русские немцы были вынуждены указывать этнические мотивы. Таким образом, нельзя автоматически исходить из того, что приводимые русскими немцами этнические мотивы и есть «правдивые» причины выезда $[12$, S. 32]. Нужно заметить, что и после распада СССР стимул указывать религиозные и этнические причины переезда в качестве основных не утратил своей актуальности, поскольку немецкими властями этничность попрежнему рассматривалась как основная предпосылка миграции.

По условиям приема русские немцы подталкиваются к тому, чтобы указывать на значимость религии и этнических причин, как основных мотивов миграции, что транслируется ими и при опросах. Кроме того, нельзя не заметить некоторого отличия в подходах российских и немецких исследователей при изучении причин миграции русских немцев. В частности, российскими исследователями, как правило, не поднимается вопрос о «возвращении», в то время как данная идея, как и формулировка «жить как немцы среди нем- 


\section{ВЛАСТЬ И ОБЩЕСТВО}

цев» в той или иной степени присутствует в опросниках исследований, проведенных в Германии после переезда [13, S. 153]. Например, в исследованиях русских немцев, проведенных в России, в расшифровке вопроса «по какой причине Вы хотите уехать?», вариант ответа «жить как немцы среди немцев» может вообще отсутствовать. Акцент ставится в основном на экономические составляющие проблемы. В частности, такие варианты ответов, как «отсутствие стабильности в России», «отсутствие работы», «отсутствие жилья» и т. д. [3, с. 29] в известной степени предопределяют выбор респондентов. Поэтому неудивительно, что в России русские немцы указывают экономические причины миграции, а после переезда «переключаются» на этнические.

В качестве одной из составляющих политических мотивов важную роль при приеме мигрантов играли также идеологические аргументы, которые были особенно актуальны во времена существования СССР. Как отмечает Б. Диц, во времена «холодной войны» эмиграция переселенцев из социалистических стран могла быть расценена как доказательство превосходства западногерманского режима [5, S. 116]. После распада Советского Союза эта причина отпала, или, по крайней мере, перестала рассматриваться как актуальная, поэтому, несмотря на упоминание политической составляющей переезда русских немцев, основной миграционный контекст группы видится авторами либо в области этничности, либо в экономической сфере.

Случай русских евреев.

Значительная часть исследователей до середины 90-х гг. в качестве одного из основных мотивов переезда русских евреев в Германию называли страх антисемитизма [14, S. 150]. Несколько позднее, в публикации 1999 г., те же авторы констатировали изменение мотивов эмиграции русских евреев. На видное место вышли «плачевное состояние экономики и нужда в странах СНГ и Балтии». На антисемитизм в данном исследовании указали $15,1 \%$ опрошенных [15, S. 49]. В то же время авторы подчеркивают, что у евреев, уезжающих из России, в противоположность к другим регионам бывшего СССР, был попрежнему отчетливо выражен страх антисе- митизма. Это отметили 56,2 \% респондентов. Такие причины, как безопасность собственной семьи и страх гражданской войны, также чаще назывались именно у евреев из России, в то время как личные и экономические причины казались несущественными [15, S. 50].

Многие авторы делают акцент не только на страхе антисемитизма, но и на других причинах, которые в основном имеют экономическую и/или политическую подоплеку. «Мотивы эмиграции советских евреев берут свои истоки в страхе антисемитизма и опасности гражданской войны. В остальном они видятся через плохую экономическую ситуацию, возникшую вследствие изменения системы» [7, S. 65]. В исследовании Ю. Крузе и М. Лернера утверждается, что основной причиной эмиграции русских евреев была политическая ситуация в стране исхода. Так считали $61,7 \%$ опрошенных. На экономические причины как доминирующие при принятии решения об эмиграции указали $55,1 \%$ респондентов. Страх антисемитизма находится на третьей позиции по значимости - 50,5 \% опрошенных [11, S. 118-119].

На экономические причины эмиграции евреев обращают внимание и другие исследователи, полагающие, что «мотивы эмиграции еврейских беженцев относятся не только к страху перед антисемитизмом и опасностью гражданской войны. Эта эмиграция не в последнюю очередь видится через затруднительную экономическую ситуацию, которая осталась после системных изменений и побудила к эмиграции» [6, S. 16]. Р. Брим, исследуя мотивы евреев, покидающих пределы СНГ, приходит к выводу, что в основе мотивации евреев лежат в большей степени экономические причины (59\%), чем причины антисемитизма, страха быть жертвами насилия и политической нестабильности (33\%), или желания воссоединения семьи ( $8 \%)$. На основе этих данных автор делает вывод, что не все еврейские эмигранты из стран СНГ являются беженцами. Только меньшую часть из них можно так определить [4, p. 79].

Тем не менее вопрос о том, а был ли страх антисемитизма именно той самой движущей силой, которая и побудила большинство русских евреев покинуть пределы СССР и впоследствии СНГ, остается открытым. В ча- 
стности, Ю. Щёпс пишет: «оспариваемым остается также вопрос, действительно ли в начале 90-х гг. сильный антисемитизм в СНГ был серьезной угрозой для евреев и высокоактуальным эмиграционным мотивом» $[16$, S. 129]. Это оставляет поле для дискуссии о том, в каком направлении должно идти понимание группы русских евреев: как общества «жертвы», или как обыкновенных экономических мигрантов. Именно смещение акцента понимания группы через ее экономическую мотивацию выезда, которое стало наблюдаться в ряде исследований [8; 9], послужило причиной для отхода от первоначальной перспективы рассмотрения русских евреев как «жертвы» и трактовки группы как экономических мигрантов.

Можно видеть, что в исследованиях мотивов миграции русских немцев и русских евреев главные расхождения авторов в основном касаются разной интерпретации значимости этнических и экономических/политических аспектов миграции. В случае с русскими евреями значимость аспекта этничности не выделяется прямо, а выражается через антисемитизм стран исхода и этническую дискриминацию евреев как группы, существующей в странах исхода. В случае русских немцев этнический аспект подчеркивается желанием мигрантов «жить как немцы среди немцев». Это трактуется авторами однозначно как этнический мотив.

Принимая во внимание данные направления исследований миграционных причин русских немцев и русских евреев, попробуем сравнить их с результатами нашего исследования, фокусируя при этом внимание на сходстве/различии между группами русских немцев и русских евреев.

Анализ. Как было указано, объект исследования ограничен группами этнически привилегированных мигрантов, а именно немецкими поздними переселенцами и еврейскими контингентными беженцами, обозначаемыми как «русские немцы» и «русские евреи» соответственно. Среди представителей данных групп в Мюнхене было проведено 43 интервью. Из них - 20 в группе русских немцев и 23 - в группе русских евреев. В контексте поставленной проблемы основной интерес представляли русскоязычные мигран- ты, приехавшие в Германию из СССР и позднее стран-наследниц Советского Союза, начиная с последнего этапа перестройки (19881989 гг.) в течение последующих 15 лет, на которые пришелся основной поток мигрантов в Германию с территории бывшего СССР. Исследование проводилось с опорой на качественную методологию с применением метода тематически-центрированного интервью. Основная идея метода заключалась в том, что респонденту предлагался набор тематических блоков, в рамках которых поступательно формулировались открытые вопросы, касающиеся только одной темы, и велось свободное обсуждение. Применение данного метода позволяло четко структурировать беседу, не «загоняя» респондента в жесткие рамки, как это происходит, например, при структурированном интервью. Это позволяло придать свободный характер интервью, которое в то же время приобретало вид связанных между собой законченных модулей.

Выборка формировалась методом «снежного кома» с учетом приведенных выше ограничений.

Случай русских немиев.

Следует выделить несколько групп причин, встречающихся в высказываниях опрошенных, которые кажутся типичными при их оценке мотивов переезда в Германию.

К первой группе относятся причины соичально-экономического характера. В данном случае переезд в Германию связывается с получением широкого спектра социальных гарантий, которые в Германии считаются нормой и касаются всех ее жителей. Это, например, гарантии личной безопасности, доступного медицинского обслуживания, бесплатного образования и т. д. К этому же относятся и удобная инфраструктура немецких городов, более широкие перспективы для детей мигрантов и т. д.

«Дело в том, что я перенес операцию. Меня еле вытащили. И мне посоветовали, что если есть возможность уехать, то надо уезжать. А еще из-за непорядка уехал, из-за неустойчивости российской политики. Еще была причина - я из-за детей уехал. А так я бы никуда не уехал. Это ведь моя родина - Россия. Я там родился» (муж., 54).

Вторая группа охватывает причины массового подражания и примера родственни- 


\section{ВЛАСТЬ И ОБЩЕСТВО}

ков. Особенно сильно это выражено у мигрантов из небольших городов и сельских поселений Казахстана. Для этой группы мигрантов тесные родственные связи имели большое значение, поэтому выбор многих родственников в пользу эмиграции часто мог быть решающим аргументом при принятии собственного решения о переезде. В этом случае ключевой мотив миграции заключался в стремлении русских немцев «быть как все», что связано со страхом потерять сложившуюся сеть социальных взаимодействий, которая «мигрировала» в Германию, независимо от воли респондента. При этом опрошенные часто не могли сами однозначно оценить преимущества или недостатки будущего переезда, поэтому решение принималось с опорой на опыт и советы родственников. Что же касается жителей крупных городов, особенно мегаполисов России, то данная тенденция выражена гораздо слабее, поскольку родственные связи здесь имели гораздо меньшее значение и советы родственников не являлись определяющими при принятии окончательного решения.

«К тому времени начался повальный отъезд из Казахстана русских в Россию. Немцы тоже большим потоком уезжали. У нас вопрос был, что если ехать, то в Германию. А туда уже уехало много родственников. Но я, честно говоря, уезжать никуда не хотела. Нас тогда еще ничего не зацепило, чтобы ехать. А было такое, стадное чувство, что вот все ехали, и мы поехали. Опять же мне не хотелось ехать, у меня не было этого чувства, но мы поехали» (жен., 56).

К третьей группе причин следует отнести возникновение процессов выталкивания по этническому признаку. Часть населения, считавшегося «русским» в ряде республик бывшего СССР, оказалось в ситуации частичной языковой и социальной изоляции, что побуждало людей к выезду из страны. В эту часть входили и русские немцы, которые в Казахстане не могли претендовать на статус «коренного народа» и (также как и русские) выдавливались из страны. Поэтому фактор выталкивания стал приобретать весомое значение при принятии решения о переезде для всех «некоренных» групп, включая и русских немцев.

«Я уже на тот момент оставалась практически без работы. Из русскоязычного на- селения кто мог - все уехали. Оставались одни казахи, которые на работу брали только своих. А мы оставались не у дел. То есть мы им не нужны были. Я бы просто не вытянула там с детьми» (жен., 36).

Четвертая группа причин связана с желанием респондентов получить личный onыm жизни на Западе и сравнить его с теми представлениями о «загранице», которые были в СССР. В данном случае «заграница» не подразумевала исключительно Германию. Запад понимался собирательно и выступал как некая привлекательная картинка, которую после длительного запрета разрешили посмотреть.

«Мне хотелось посмотреть, что такое заграница. Мы не имели возможности выехать дальше нашего города. Дальше Ленинграда, если к родственникам. И приехав сюда, мы уже на второй год могли позволить себе поехать отдыхать на море. Я здесь первый раз море увидела» (жен., 42).

Все вышеупомянутые группы причин не встречаются в высказываниях респондентов отдельно друг от друга. Как правило, они тесно взаимосвязаны между собой. Речь идет лишь о возможном доминировании той или иной причины переезда в конкретном случае. Обращает на себя внимание сильное влияние неформальных сетей связей на принятие решения о миграции, когда часть опрошенных делали «как все». Родственники и знакомые респондентов формировали «картину Германии», которая была, вне всякого сомнения, привлекательной. «Там» было лучше, чем «здесь». Это стало аксиомой в умах многих русских немцев, что существенно повлияло на формирование выездных настроений в группе.

Случай русских евреев.

При оценке мотивов, побудивших русских евреев мигрировать в Германию, речь также шла о комплексе взаимоувязанных причин, значимость которых варьировалась в зависимости от темы обсуждения и актуальных установок респондента. Заметны причины экономического характера. При этом экономическая мотивация переезда связывается обычно не с желанием разбогатеть, открыть собственный бизнес и т. д., а с получением минимальных гарантий в рамках социальной помощи. В ряде случаев речь шла о «бегстве 
от нищеты». Также следует подчеркнуть, что экономические причины очень редко фигурировали отдельно от других мотивов переезда. Чаще всего они рассматривались респондентами как неотъемлемая часть общей ситуации в стране и сложившихся личных семейных обстоятельств.

«Тогда это был полный развал страны. Пустые полки, зарплаты я уже не получала. Полная бесперспективность. Я чувствовала, что выхожу уже за грань нищеты. А тут была возможность такая. Ну, я и понимала, что хуже уже не будет, чем то, что у нас делалось в Союзе» (жен., 64).

Очень заметно желание респондентов жить в стабильном и предсказуемом обществе с действующими законами. Разочарование опрошенных в обществах стран исхода, их политических режимах и отсутствие видимых перспектив улучшения ситуации повлияло на принятие решения о выезде. Характерно, что данная причина фигурировала как основная и для тех респондентов, которые не ощущали финансовых проблем в странах исхода и вообще никак не упоминали экономической подоплеки миграции. В ряде случаев решающим моментом оказалось то, что у них впервые появилась возможность покинуть пределы постсоветского пространства. Данные причины основаны на особенностях социализации в советском обществе и особом восприятии «заграницы», знакомство с которой для большинства советских людей было недоступно. Возможность «открытия» для себя Запада стала одним из важных мотивов, побудивших респондентов к миграции.

«Мне хотелось посмотреть заграницу, архитектуру, замки... И меня, как и любого бывшего советского человека, притягивал Запад. Я не могу сказать, что мы совсем уж так плохо жили, нет. Но они жили лучше» (муж., 64).

Интересно и то, что Германия здесь не рассматривалась как основная цель миграции. Функции немецкого государства сводились к предоставлению возможности свободного перемещения по странам Еврозоны.

Упоминание респондентами дискриминации по этническому признаку следует отметить особо, поскольку этому моменту в ряде работ по русским евреям уделяется повышен- ное внимание. Однако в нашем исследовании эта причина слабо представлена. Причем характерно, что, говоря об этнической дискриминации, респонденты упоминают не только антисемитизм, но и случаи этнической дискриминации русского населения.

«Я из Таллинна сюда приехала. Тогда уже независимая Эстония была. И они, особенно когда почувствовали себя свободными... Они в принципе русских ненавидели. Не все, конечно. Ну, я поэтому и уехала... Потом в Эстонии тогда все развалилось, работы никакой не было» (жен., 55).

Следует отметить, что данный случай не является типичным и по нему нельзя судить о наличии какой-либо тенденции. Показательно лишь то, что еврейская эмигрантка покидает страну, возникшую на постсоветском пространстве, по причине этнической дискриминации части населения, к которому она (кажется) не имеет отношения.

Создается впечатление, что русские евреи, хорошо зная о проявлениях антисемитизма, не придают этому факту большого значения. По крайней мере, респонденты вспоминают об этом только тогда, когда им задается уточняющий вопрос по поводу антисемитизма как причины эмиграции. При этом респонденты не склонны к тому, чтобы называть антисемитизм главной причиной переезда.

«На момент выезда, да и до этого все время, сколько я там жил, бытового антисемитизма не было. Был же государственный антисемитизм, который был везде. Но оттого, что я еврей, я никогда не страдал. И если я скажу, что я приехал сюда потому, что там был антисемитизм и все такое, то это не так. Вранье все это. Я просто оставался там один. Это главная причина» (муж., 73).

В целом весь вышеизложенный спектр миграционных мотиваций русских евреев можно свести к следующим трем группам. Во-первых, это группа социально-экономических причин. К ним относятся все социальные преимущества немецкого общества, к которым получила доступ еврейская эмиграция. Данная группа причин тесно связывается с выталкивающими факторами социально-экономического характера, возникшими в СССР и впоследствии в странах-наследницах Советского Союза. Обобщая весь комплекс 


\section{ВЛАСТЬ И ОБЩЕСТВО}

причин, описываемых здесь как социальноэкономические, можно сказать, что основная мотивация группы была направлена на осуществление возможности стать частью общества с более высоким жизненным стандартом, более понятными социальными правилами и определенными гарантиями в завтрашнем дне.

Самой неожиданной причиной эмиграции русских евреев оказалось, пожалуй, стремление заметной части группы опрошенных увидеть другую (не советскую) реальность и иметь беспрепятственную возможность перемещения по странам Европы. Именно это лежит в основе второй группы причин, которую можно обозначить как желание «увидеть загранииу».

К третьей группе причин эмиграции следует отнести дискриминацию по этническому признаку. Главной интригой здесь является то, что группа русских евреев испытывала дискриминацию в странах бывшего СССР не только как евреи, но и как русские, например, в случае если они выезжали из Эстонии. Следует отметить, что данная тенденция не является преобладающей среди опрошенных. Однако в глаза бросается явное сходство с ситуацией в группе русских немцев, которые в Казахстане также испытывали случаи этнической дискриминации не только как немцы, но и как русские.

Результаты. В качестве одного из интересных мотивов миграции следует выделить стремление «увидеть заграницу». Такая мотивация, несмотря на кажущуюся естественность для выходцев из бывшего СССР, все же представляется довольно экзотичной, поскольку не несет в себе явной рациональной составляющей, то есть никак не связана ни с карьерой, ни с преференциями материального характера. Но в целом эта (почти что иррациональная) тяга респондентов узнать о том, «как живут люди на Западе» является очень заметным мотивом миграции. Этот мотив очень мало, или даже никак не связан ни с экономическими причинами, ни с этнической дискриминацией и конкретно с антисемитизмом, ни с желанием респондентов «жить в демократическом обществе». Условия советского государства, транслирующие только одну идеологию и только одно миро- понимание, не давали возможности советским людям на практике ощутить другую реальность. Это порождало особую мотивацию части респондентов «увидеть Запад». В данном случае «Западом» выступала ФРГ, поэтому для некоторых респондентов представления о Германии приравнивались к представлениям о Западе в целом.

«Знаете, даже странно, вот я когда сюда ехала, я даже не отдавала отчета, что это Германия. Ну, просто ехала заграницу и все. Кудато на Запад, в другой мир» (жен., 57).

Следует признать, что появление этой причины в разряде значимых в данном исследовании оказалось неожиданным. Кроме того, настораживает тот факт, что в других работах данная причина вообще не упоминается исследователями.

Думается, что здесь следует принимать во внимание различные культурные реальности западногерманских исследователей, задающих тон в изучении русских немцев и русских евреев, с одной стороны, и бывших советских граждан, с другой. Вполне вероятно, что для многих исследователей русскоязычных групп сама идея о том, что желание «увидеть заграницу» может быть причиной миграции, даже не возникала. Соответственно, данная группа вопросов не включалась в исследовательский инструментарий, так как сам феномен «заграницы», обобщающий все государства несоциалистического лагеря, отсутствовал в культурных практиках населения западноевропейских стран. Между тем наличие собирательного образа «заграницы» в советской культуре, его глубокое эмоциональное наполнение стало основой для формирования поведенческих образцов массового характеpa, которые не принимались во внимание большинством западногерманских авторов. В итоге одна из значимых причин миграции, в разной степени выраженная во всех русскоязычных группах, оказалась за рамками внимания исследователей.

В качестве другой заметной миграционной мотивации следует выделить сощиальноэкономические причины. Квинтэссенция группы социально-экономических причин сводится к тому, что многие респонденты ищут в Германии чувство социальной определенности как рядового гражданина, которую они 
потеряли при распаде СССР и которую им были не в состоянии дать ни одна из страннаследниц Советского Союза, включая и Россию. Поэтому основа социально-экономической мотивации мигрантов заключалась в первую очередь в попытке приобрести социальную «точку опоры», которую им и предложила Германия, подарив перспективу новой идентичности (в первую очередь политической) и полноправное членство в стабильном обществе с прозрачными правилами игры и определенным дальнейшим развитием. Кажется, что эта идея слабо артикулируется исследователями, и основное внимание уделяется, чаще всего, чисто экономическим преференциям, получаемым мигрантами в виде пособий, страховок, интеграционных курсов и т. д.

Также нельзя обойти вниманием и некоторые дискуссионные моменты, касающиеся интерпретации степени значимости этничности и этнической дискриминачии как причин миграции групп русских немцев и русских евреев.

Например, согласно данным ряда исследований по русским евреям, именно антисемитизм являлся одной из важнейших причин выезда евреев из СССР и стран-наследниц Советского Союза. Действительно, большинство респондентов, как в группе русских немцев, так и русских евреев, отметили, что им в той или иной степени приходилось сталкиваться с фактами этнической дискриминации. И этот результат совпадает с данными других исследований. Но возникает вопрос, по какой именно этничности были дискриминируемы русские немцы и русские евреи в CCCP, а по какой - в странах-наследницах СССР? В большинстве исследований считается, что русские евреи дискриминировались всегда как евреи, а русские немцы - как немцы. Другая характеристика этничности данных групп - «русские», присутствующая, как у русских немцев, так и русских евреев, обычно выпадает из поля зрения исследователей.

Между тем касательно случая постсоветских государств дискриминация русских немцев и русских евреев может иметь место по основанию «не той» этничности. Если в СССР имела место дискриминация русских немцев как немцев и русских евреев как евреев, то на постсоветском пространстве обе группы могли дискриминироваться как русские, а не как евреи или немцы. Говоря другими словами, дискриминироваться по конкретному этническому признаку, не обладая, или «недостаточно обладая» этим признаком. Таким образом, в ряде работ мы имеем дело с неоправданным упрощением ситуации, когда условия СССР и его национальная политика приписываются и государствам, возникшим на его территории. В этой связи дискриминация как причина миграции должна рассматриваться применительно к двум случаям: во-первых, случай СССР; во-вторых, случай государствнаследниц Советского Союза. Поэтому нельзя утверждать, что именно дискриминация по признаку какой-либо определенной этничности послужила причиной миграции, так как, вероятнее всего, в случае русскоязычных групп мы имеем дело с «плавающей» этничностью, которая может быть предложена или навязана индивидам.

Доминирующее во многих современных исследованиях предположение о том, что дело приходится иметь с устойчивыми этническими группами, привело многих авторов к явному преувеличению роли этничности для понимания самоидентификации участников этих групп. Этничность часто рассматривается как ключевой маркер группы и увязывается с ее культурными характеристиками, предполагающими существование определенного нормативного аппарата, на основе которого выстраиваются поведенческие и ментальные образцы членов группы.

Следует подчеркнуть, что многие авторы были просто вынуждены использовать «фиксированную» этничность в своих исследованиях, поскольку категория этничности является изначально заданной соответствующими законами ФРГ, регламентирующими правила приема русских немцев и русских евреев. Поэтому «обойти» вопрос этничности, не поставив при этом под сомнение всю немецкую миграционную политику в отношении указанных групп, не представляется возможным. Фактически в случае русских немцев и русских евреев мы имеем дело с носителями ментальных и поведенческих образцов советской культуры, в рамках которой и состоялась социализация участников обеих групп. Советская действительность задава- 


\section{ВЛАСТЬ И ОБЩЕСТВО}

ла другие, отличные от этнических, рамки самоопределения, в которых размещались все этнические группы, включая русских немцев и русских евреев. «Во времена СССР российские евреи, как и все население страны, были органической частью советского народа, который, как известно, считался “новой исторической общностью”. Действительно, как “простые люди" из числа евреев, так и выдающиеся их представители - О. Мандельштам и А. Райкин, М. Ботвинник и Л. Утесов, Ф. Раневская и многие другие - ощущали себя представителями не еврейской, а советской культуры» [2, с. 52]. «Жизнь в советской стране и, более того, в крупном городе, практически разрушила прежний конструкт этничности, в большинстве случаев немецкая идентичность сменилась на советскую» [1, с. 106].

Это заставляет предположить, что культурные границы групп не совпадают с их этническими границами. То есть по этничности группы мы не можем судить о ее культуре, включающей образцы поведения, способы мышления, привычки и т. д. Создается впечатление, что категории этничности и культуры никак не согласуются между собой. Причем, если категория культуры увязывается с образом мыслей и с конкретным ценностнонормативным аппаратом, который разделяется большинством группы, то категория этничности служит лишь для того, чтобы дать условное обозначение носителям данного ценностно-нормативного аппарата. В этом свете этничность как критерий, с помощью которого исследователи пытаются охватить группы русских немцев и русских евреев, видится несостоятельным, а использование принятых этничностей, как основных характеристик для обозначения и отграничения исследуемых групп, кажется неоправданным.

\section{ПРИМЕЧАНИЕ}

${ }^{1}$ Авторы благодарят Фонд Александра Гумбольдта за поддержку проекта.

\section{СПИСОК ЛИТЕРАТУРЫ}

1. Бредникова, О. «Вообще-то я русский... Но когда у нас в Питере бросают мимо мусор, я чувствую, что я все-таки немец...» / О. Бредникова // Конструирование этничности. Этнические общины Санкт-Петербурга / под ред. В. Воронков, И. Освальд. - СПб. : Дмитрий Буланин, 1998. С. $97-135$.

2. Рывкина, Р. Евреи в современной России / Р. Рывкина // Общественные науки и современность. -1996 . - № 5. - С. 47-58.

3. Смирнова, Т. Современное состояние идентичности, языка и культуры немцев России / Т. Смирнова // Диаспоры. - 2010. - № 2. - С. 191-214.

4. Brym, R. The Jews of Moscow, Kiev and Minsk. Identity, Antisemitism, Emigration / R. Brym. N. Y. : New York University Press, 1994. - 93 p.

5. Dietz, B. Die Zuwanderung und Integration von (Spät) Aussiedlern im Kontext deutscher und europäischer Migrationspolitik / B. Dietz // Die Russlanddeutschen in den Migrationsprozessen zwischen den GUS-Staaten und Deutschland / B. Dietz, O. Luchterhand, A. Eisfeld (Hg.). - Göttingen : Der Göttinger Arbeitskreis, 2008. - S. 115-132.

6. Gruber, S. Hochqualifiziert und arbeitslos. Jüdische Kontingentflüchtlinge in NordrheinWestfalen. Problemaspekte ihrer beruflichen Integration. Eine empirische Studie / S. Gruber, H. Rüßler. - Opladen : Leske + Budrich, 2002. - 225 s.

7. Haug, S. Jüdische Zuwanderer in Deutschland / S. Haug, M. Wolf // Neue Zuwanderergruppen in Deutschland / F. Swiaczny, S. Haug (Hg.). - Heft 118. Wiesbaden : Bundesinstitut für Bevölkerungsforschung beim Statistischen Bundesamt, 2006. - S. 65-82.

8. Kessler, J. Homo Sovieticus in Disneyland: the Jewish Communities in Germany Today/ J. Kessler // The new German Jewry and the European Context. The Return of the European Jewish Diaspora / ed. by Y. M. Bodemann. - N. Y. : Palgrave Macmillan, 2008.P. 131-143.

9. Körber, K. Juden, Russen, Emigranten. Identitätskonflikte jüdischer Einwanderer in einer ostdeutschen Stadt / K. Körber. - Frankfurt ; N. Y. : Campus Verlag, 2005. - $191 \mathrm{~s}$.

10. Ködderitzsch, P. Zur Lage, Lebenssituation, Befindlichkeit und Integration der rußlanddeutschen Aussiedler in Berlin. Teil I, Studie / P. Ködderitzsch. Frankfurt am Main : Peter Lang Verlag, 1997.-S. 11-155.

11. Kruse J. Jüdische Emigration aus der ehemaligen Sowjetunion nach Deutschland. Aspekte eines neuen Migrationssystems / J. Kruse, M. Lerner. Potsdam : Selbstverlag des Instituts Humangeographie und Geoinformatik der Universität, 2000. - 151 s.

12. Kusterer, K. Forschungsprojekt "Deutsche in der Sowjetgesellschaft". Arbeitsbericht Nr. 13. Ethnische Identität bei den Deutschen in der Sowjetunion. Ergebnisse einer Befragungsstudie mit deutschen Spätaussiedlern aus der Sowjetunion / K. Kusterer. München : Osteuropa Institut, 1990. - 34 s. 
13. Riek, G.-A. Die Migrationsmotive der Rußlanddeutschen. Eine Studie über die sozialintegrative, politische, ökonomische und ökologische Lage in Rußland / G.-A. Riek. - Stuttgart : Ibidem-Verlag, 2000. - $554 \mathrm{~s}$.

14. Schoeps, J. Russische Juden in Deutschland. Integration und Selbstbehauptung in einem fremden Land / J. Schoeps, W. Jasper, B. Vogt. - Weinheim : Beltz Athenäum Verlag, 1996. - 366 s.

15. Schoeps, J. "Jüdische Zuwanderer aus der GUS - zur Problematik von soziokultureller und generationsspezifischer Integration". Eine empirische Studie des Moses Mendelssohn Zentrums 1997-1999 / J. Schoeps, W. Jasper, B. Vogt // Ein neues Judentum in Deutschland? Fremd- und Eigenbilder der russischjüdischen Einwanderer / J. Schoeps, W. Jasper, B. Vogt (Hg.). - Potsdam : Verlag für Berlin-Brandenburg, 1999. - S. 13-139.

16. Schoeps, J. Ein neues Judentum in Deutschland? Zur Debatte um die Zukunftsperspektiven jüdischer Zuwanderer aus der früheren Sowjetunion und deren Nachfolgestaaten / J. Schoeps // Russische Juden und transnationale Diaspora / J. Schoeps, K. Grözinger, u.a. (Hg.). - Berlin/Wien : Philo Verlagsgesellschaft mbH, 2005. -S. 119-132.

17. Tröster, I. Wann ist man integriert? Eine empirische Analyse zum Integrationsverständnis Rußlanddeutscher / I. Tröster. - Frankfurt am Main : Peter Lang Verlag, 2003. -193s.

18. Vogel, K. Psychosoziale Schwierigkeiten im Integrationsprozess von russlanddeutschen Spätaussiedlern. Qualitative Fallanalysen / K. Vogel. Stuttgart : Ibidem Verlag, 2008. - 506 s.

\section{REFERENCES}

1. Brednikova O. «Voobshche-to ya russkiy... No kogda u nas $\mathrm{v}$ Pitere brosayut mimo musor, ya chuvstvuyu, chto ya vse-taki nemets...» [“Actually, I'm Russian.... But When We Are in St. Petersburg by Throwing the Garbage, I Feel like I'm still a German"]. Voronkov V., Osvald I., eds. Konstruirovanie etnichnosti. Etnicheskie obshchiny Sankt-Peterburga [Construction of Ethnicity. Ethnic Communities of Saint Petersburg]. Saint Petersburg, Dmitriy Bulanin Publ., 1998, pp. 97-135.

2. Ryvkina R. Evrei v sovremennoy Rossii [The Jews in Modern Russia]. Obshchestvennye nauki $i$ sovremennost [Social Sciences and Contemporary World], no. 5, 1996, pp. 47-58.

3. Smirnova T. Sovremennoe sostoyanie identichnosti, yazyka i kultury nemtsev Rossii [The Current State of Identity, Language and Culture of Germans of Russia]. Diaspory, 2010, no. 2, pp. 191-214.
4. Brym R. The Jews of Moscow, Kiev and Minsk. Identity, Antisemitism, Emigration. New York, New York University Press, 1994. 93 p.

5. Dietz B. Die Zuwanderung und Integration von (Spät) Aussiedlern im Kontext deutscher und europäischer Migrationspolitik. Luchterhand O., Eisfeld A., Hrsg. Die Russlanddeutschen in den Migrationsprozessen zwischen den GUS-Staaten und Deutschland. Göttingen, Der Göttinger Arbeitskreis, 2008, S. 115-132.

6. Gruber S., Rüßler H. Hochqualifiziert und arbeitslos. Jüdische Kontingentflüchtlinge in Nordrhein-Westfalen. Problemaspekte ihrer beruflichen Integration. Eine empirische Studie. Opladen, Leske + Budrich, 2002. 225 S.

7. Haug S., Wolf M. Jüdische Zuwanderer in Deutschland. Swiaczny F., Haug S., Hrsg. Neue Zuwanderergruppen in Deutschland. Wiesbaden, Bundesinstitut für Bevölkerungsforschung beim Statistischen Bundesamt, 2006, Heft 118, S. 65-82.

8. Kessler J. Homo Sovieticus in Disneyland: The Jewish Communities in Germany Today. The New German Jewry and the European Context. The Return of the European Jewish Diaspora. New York, Palgrave Macmillan, 2008, pp. 131-143.

9. Körber K. Juden, Russen, Emigranten. Identitätskonflikte jüdischer Einwanderer in einer ostdeutschen Stadt. Frankfurt, New York, Campus Verlag, 2005. $191 \mathrm{~S}$.

10. Ködderitzsch P. Zur Lage, Lebenssituation, Befindlichkeit und Integration der rußlanddeutschen Aussiedler in Berlin. Teil I, Studie. Frankfurt am Main, Peter Lang Verlag, 1997, S. 11-155.

11. Kruse J., Lerner M. Jüdische Emigration aus der ehemaligen Sowjetunion nach Deutschland. Aspekte eines neuen Migrationssystems. Potsdam, Selbstverlag des Instituts Humangeographie und Geoinformatik der Universität, 2000. 151 S.

12. Kusterer K. Forschungsprojekt „,Deutsche in der Sowjetgesellschaft". Arbeitsbericht Nr. 13. Ethnische Identität bei den Deutschen in der Sowjetunion. Ergebnisse einer Befragungsstudie mit deutschen Spätaussiedlern aus der Sowjetunion. München, Osteuropa Institut, 1990. 34 S.

13. Riek G.-A. Die Migrationsmotive der Rußlanddeutschen. Eine Studie über die sozialintegrative, politische, ökonomische und ökologische Lage in Rußland. Stuttgart, IbidemVerlag, 2000. $554 \mathrm{~S}$.

14. Schoeps J., Jasper W., Vogt B. Russische Juden in Deutschland. Integration und Selbstbehauptung in einem fremden Land. Weinheim, Beltz Athenäum Verlag, 1996. $366 \mathrm{~S}$.

15. Schoeps J., Jasper W., Vogt B. "Jüdische Zuwanderer aus der GUS - zur Problematik von soziokultureller und generationsspezifischer Integration". 


\section{ВЛАСТЬ И ОБЩЕСТВО}

Eine empirische Studie des Moses Mendelssohn Zentrums 1997-1999. Schoeps J., Jasper W., Vogt B., Hrsg. Ein neues Judentum in Deutschland? Fremd- und Eigenbilder der russisch-jüdischen Einwanderer. Potsdam, Verlag für Berlin-Brandenburg, 1999, S. 13-139.

16. Schoeps J. Ein neues Judentum in Deutschland? Zur Debatte um die Zukunftsperspektiven jüdischer Zuwanderer aus der früheren Sowjetunion und deren Nachfolgestaaten. Schoeps J., Grözinger K., u.a., Hrsg. Russische Juden und transnationale Diaspora. Berlin, Wien, Philo Verlagsgesellschaft mbH, 2005, S. 119-132.

17. Tröster I. Wann ist man integriert? Eine empirische Analyse zum Integrationsverständnis Rußlanddeutscher. Frankfurt am Main, Peter Lang Verlag, 2003. $193 \mathrm{~S}$.

18. Vogel K. Psychosoziale Schwierigkeiten im Integrationsprozess von russlanddeutschen Spätaussiedlern. Qualitative Fallanalysen. Stuttgart, Ibidem Verlag, 2008. 506 S.

\section{Information About the Authors}

Viacheslav D. Popkov, Doctor of Sciences (Sociology), Doctor of Philosophy (Technische Universität Berlin), Director, Institute of Social Researches and Analytics, Nikitina St., 40/49-5, 248003 Kaluga, Russian Federation, v-831p@yandex.ru, https://orcid.org/0000-0002-4531-0358

Ekaterina A. Popkova, Candidate of Sciences (Philology), Associate Professor, Bauman Moscow State Technical University Kaluga Branch (National Research University), Bazhenova St., 2, 248000 Kaluga, Russian Federation, ekaterina.popkova@lenta.ru, https://orcid.org/0000-0001-8734-8330

\section{Информация об авторах}

Вячеслав Дмитриевич Попков, доктор социологических наук, доктор философии (Берлинский технический университет), директор, Институт социальных исследований и аналитики, ул. Никитина, 40/49-5, 248003 г. Калуга, Российская Федерация, v-831p@yandex.ru, https://orcid.org/0000-0002-4531-0358

Екатерина Анатольевна Попкова, кандидат филологических наук, доцент, Калужский филиал Московского государственного технического университета им. Н.Э. Баумана, ул. Баженова, 2, 248000 г. Калуга, Российская Федерация, ekaterina.popkova@lenta.ru, https://orcid.org/0000-0001-8734-8330 